\section{Histoire Épistémologie Langage}

42-1 | 2020

La grammaire arabe étendue

\title{
Turkic morphology seen by the Arabic grammarians. The passive
}

\section{Robert Ermers}

\section{(2) OpenEdition \\ 1 Journals}

Electronic version

URL: https://journals.openedition.org/hel/520

DOI: 10.4000/hel.520

ISSN: 1638-1580

\section{Publisher}

Société d'histoire et d'épistémologie des sciences du langage

\section{Printed version}

Date of publication: 28 September 2020

Number of pages: $73-92$

ISSN: 0750-8069

\section{Electronic reference}

Robert Ermers, "Turkic morphology seen by the Arabic grammarians. The passive", Histoire

Épistémologie Langage [Online], 42-1 | 2020, Online since 28 October 2021, connection on 29 October 2021. URL: http://journals.openedition.org/hel/520 ; DOI: https://doi.org/10.4000/hel.520

This text was automatically generated on 29 October 2021.

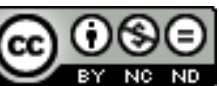

$\mathrm{HEL}$ is licensed under a Creative Commons Attribution-NonCommercial-NoDerivatives 4.0 International License 


\title{
Turkic morphology seen by the Arabic grammarians. The passive
}

\author{
Robert Ermers
}

\section{Introduction: the sources}

1 Arabic treatises of other languages present an intriguing type of source material for a number of reasons. These treatises, written by specialists educated in the Arabic grammatical tradition, deal with Turkic vocabulary, grammar, morphology and phonology. In their concise descriptions and analyses, they apply extant concepts, yet they occasionally find that they have to adapt them to this new language. In this contribution, I intend to analyse what their authors write about the passive and about passive constructions. ${ }^{1}$

The sources used for this paper are the following:

- Dīwān Lug̀āt at-Turk by Maḥmūd al-Kāšğarī (eleventh century; ed. Kültür Bakanlı̆̆ı 1990);

- The Margin Grammar - a large compilation of sections on Turkic grammar (eleventhfourteenth century) in the margins of a copy of the Kitāb al-'Idrāk Veli ed-Din manuscript;

- Kitāb al-'Idrāk li-Lisān al-'Atrāk by 'Abū Ḥayyān al-'Andalusī (fourteenth century; ed. Caferoğlu 1931);

- Al-Tuhfa al-Zakiyya fi al-Luga al-Turkiyya, anonymous (fourteenth century; ed. Halasi-Kun 1942);

-Kitāb al-Qawānin al-Kulliyya li-Ḍabṭ al-Lugaa al-Turkiyya, anonymous (fourteenth century; ed. Kilisli 1928);

- Kitāb Hilyat al-Insān wa-Halbat al-Lisān by Ǧamāl al-Dīn ibn al-Muhannā (fourteenth century; ed. Kilisli 1921).

3 Most of them date from the fourteenth century, the one exception being Diwān whose original dates from the eleventh century (al-Kāšğarī, Dīwān; Auezova 2005; Dankoff and Kelly 1982-1985). ${ }^{2}$ All of these sources have been edited and published, except the one I have called the Margin Grammar. 

or Yellow Uygur (Clauson 1965). The fourteenth-century sources describe the language of Mamlūk military slaves in Egypt and Syria, who spoke a Kipchak language - probably (Crimean) Tatar- with Oguz (Turcoman) material (Berta 1998). A precise determination of the Turkic language described in each work is complicated, one reason being that there are large overlaps between languages and subgroups regarding morphology and vocabulary, and another that the Arabic script as it is used in the sources does not easily allow for the expression of nuances in vowels, such as the distinction between e/ a, o/u and ö/ü respectively (Ermers 1999).

7 From both morphological and syntactical perspectives, there are considerable differences between Arabic and Turkic. Most Arabic nouns, verbs, and adjectives can be derived from a root, whereas in Turkic word formation is based upon stems. Not surprising, therefore, is the notion that in Arabic grammar a central concept of a verbal root (rather than a stem) was developed, consisting of consonants to which other consonants (hurūf, sg. harf) are added as prefixes and infixes, thus adding derived meanings ( $m a^{\prime} n \bar{a}$, pl. ma' ānī) and forming new patterns (wazn, pl. 'awzān) that are more or less predictable in form and function. Probably for this reason, the Arabic grammatical tradition could develop into a functional grammar, in which given forms (and positions) are correlated with certain meanings (see e.g. Bohas and Guillaume 1984; Owens 1988 \& 1990; Versteegh 1995 \& 1997; Sheyhatovitch 2018: 169ff; Ayoub and Versteegh 2018). This perspective was enhanced by the divine status of Arabic as the language of the Qur'ān, which, it was believed, thus could only have been chosen because of its perfectness and logic in form and structure. As this perspective on grammar was the only one available, all scholars were educated in this model regardless of their origin.

\section{Passive in Arabic and in Turkic}

\subsection{Arabic morphology: consonants of augmentation (hurūf al- ziyāda)}

8 Arabic uses morphological infixes, prefixes and suffixes which are placed onto a threeconsonantal root. In the Arabic grammatical tradition, the notion of prefixes and infixes to this root is illustrated in an abstract way with the help of the paradigmatical 
root $f^{\prime}-l$, which in turn is derived from the verb fa' ala 'to do'. ${ }^{3}$ When filled with the appropriate vowels, the pattern $f a^{\prime}$ ala signifies 'he did'.

9 With the help of the appropriate paradigmatic form, the base consonants from any root can easily be distinguished from any additions. In Arabic grammar, the augmented meaningful elements are called hurüf al-ziyāda; all augments are consonants. For example, the augmented consonant in the paradigmatical form ' $a$ - $f$ 'ala (paradigm IV in Western studies of Arabic) is ' $a$, and the same holds for the prefix in-, in-fa' ala where the augment is $n$ only (paradigm VII). After the insertion of the pre- and infixes, often a (secondary) shift of the vowels (naql al-haraka) occurs, for example, often the first root consonant, $f-$, loses its vowel.

In some paradigms, meanings are added by the simultaneous augmentation of two consonants. For example, the paradigm (VI) $\boldsymbol{t} \boldsymbol{a}-\mathrm{f}-\overline{\boldsymbol{a}}$-' $a l a$ signifies reciprocity, i.e. the action of the verb is carried out together or reciprocally by several agents.

11 Note that in the Arabic morphological tradition the concept of long vowels as morphemes did not exist. The so-called long vowels were understood as a sequence of a consonant, a glide, preceded by a vowel sign: $\bar{a}=/ \mathrm{a} / /{ }^{4} \bar{l}=/ \mathrm{iy} /, \bar{u}=/ \mathrm{uw} /$. In this way, for example, the verbal pattern of the conative form, f $\bar{a}^{\prime} a l a$, is understood as /fa"'ala/, and the additional meaning is attributed to 'alif, represented as /"/.

Earlier (Ermers 1999: 270-282) I analysed how Arab grammarians dealt with transitivity and causativity in Turkic. My conclusions were that they tried to uphold their theories regarding the correlations between form and function for Turkic as well (see also Ermers 2007). Yet they had to recognize that in other languages functions could be expressed by different syntactical and morphological elements that did not resemble their Arabic counterparts. ${ }^{5}$ They were forced, to some extent, to engage in comparative and universal linguistics. In this contribution, I intend to examine how they dealt with the passive form.

\subsection{Two types of passivity in Arabic}

In Arabic grammar, there are two distinct notions of the passive. The first is the socalled internal or apophonic passive of the verb, on the pattern fu'ila. This passive stands out in Arabic grammar because it is not expressed by means of an infix or, in Arabic terms, a meaningful particle, but by a vowel change: $f a^{\prime}$ ala $\rightarrow$ fu'ila. The imperfect tense is subjected to changes in the pattern too: $y a f^{\prime}$ ilu $\rightarrow$ yuf' alu. The subject of an internal passive verb is referred to in Arabic grammatical theory as an-năa ib 'an al$f \bar{a}^{\prime} i l$, which can be translated as "subject by proxy" or "substitute subject" (Soltan 2009: 535). The verb is "built for the patient" or "the logical object" (mabni li-l-maf ūl).

In the traditional Arabic grammatical theory, passivization is regarded as a process in which the agent of a transitive verb ( $f^{\prime} l$ muta'addin) is deleted or kept hidden or "unknown" (mağhül), although not absent, leaving the former object and the verb (Bazzi-Hamzé 2007b: 94). "The subject of the apophonic passive in Arabic is obviously not the agent of the process but rather one who is affected by the process" (Maalej 2008: 224).

15 This new situation is reflected in the verb, which assumes a new vowel pattern. Then there occurs a (superficial) syntactical shift, in which the direct object of the original 
verb assumes the subject position, i.e. the syntactic role of agent, and receives a corresponding nominative case ending (Carter 1981: 168ff).

The second way for indicating a passive is the use of the pattern infi $\bar{a}$ al. This pattern indicates an action without an evident cause:

The infi'al-pattern by itself expresses an action which the subject carries out by itself, without an agent being implied. According to Abboud-Haggar (2006: 616), it "was used as an alternative for the internal passive" in early texts, such as Qur' anic Arabic.

However, the infi'āl pattern is also used in relation to the semantical notion of muțāwa'a 'compliance', where there is a cause implied; hence Larcher's (2003: 69) interpretation as a 'résultatif'. Versteegh (2014: 119) explains the morphological reasoning behind compliance as follows:

Muțāwa' $a$ was regarded as the opposite of ta'diya, that is, decreasing the valency of the verb with one, for example, kasara 'to break [transitive]' versus inkasara 'to break [intransitive]'; 'allama 'to instruct someone about something' versus ta' allama 'to be instructed, to become learned in something' (Larcher 2012: 75-77). What mattered to the grammarians was the fact that the augment (ziyāda) correlated with an additional meaning.

"[t]here is implicit causation underlying all forms of compliance" summarizes Maalej (2008: 225), e.g. fatahtu l-bāba fa-nfataha 'I opened the door and it opened' (An-Nādirī 1995: 353 apud Maalej 2008: 225). An-Nādirī, still according to Maalej (2008: 226), writes that the complier is not necessarily intransitive (lāzim), it can also be transitive

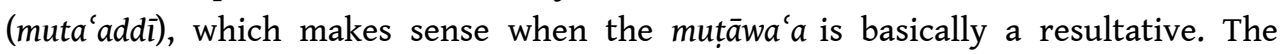
muțāwa' $a$, from a morphological perspective, therefore does not depend on one single verbal pattern, but can be expressed with several, intransitive and transitive, i.e., VII infi'äl, infa'ala; VIII ifti'âl, ifta'ala ġamamtu-hu fa-ġtamma 'I saddened him, so he was filled with grief'; V tafa" "ul, tafa" ala: kassartu l-'aqlāma fa-takassarat 'I broke the pencils, so they broke' (Maalej 2008: 226), and others. ${ }^{6}$ Larcher (2009: 642) writes that Form VII itself is already "the resultative of Form I", although "in many dialects it is used as a passive of the base form." The internal passive has become rare in modern Arabic dialects, and this process must have begun a long time ago (Carter 1981: 171). It subsists in some modern dialects on the Arabian Peninsula, e.g. in Qatar it occurs with the $u-i$ form, e.g. had qutil hina? 'was somebody killed here?' (Belova 2009: 306), while for Oman the imperfect $3 \mathrm{msg}$ form prefix has been registered, e.g. yibā' 'it is sold' (Al-Balushi 2016: 107; for Yemen see Simeone-Senelle 1997: 407). Instead of the internal passive, therefore, in most variants of Arabic the passive is expressed by means of consonantal prefixes and infixes to the verbal root. As a consequence, the distinctions between the agent-less fu'ila passive on the one hand and patterns like infi' $\bar{a} l$ on the other have disappeared.

\begin{tabular}{|l|l|l|}
\hline (1) & duriba & zayd-un \\
\hline & hit.PASS.3sg.PAST & Zayd-NOM \\
\hline & \multicolumn{2}{|l|}{ 'Zayd was hit [by someone]' } \\
\hline
\end{tabular}

\begin{tabular}{|l|l|l|}
\hline$(2)$ & in-kasara & al-ka's-u \\
\hline
\end{tabular}




\begin{tabular}{|l|l|l|}
\hline & COMPL-break.3sg.PAST & DEF-glass-NOM \\
\hline & 'the glass broke (by itself)' \\
\hline
\end{tabular}

\subsection{Passive forms in Turkic languages}

19 In all Turkic languages, semantic and voice changes to verbs are added to a stem. The morphemes added can involve one or more consonants (and occasionally vowels). The most common passive suffix is -(V)l-, ört- 'cover' $\rightarrow$ ört-ül- 'be covered', kör- 'see' $\rightarrow$ kör-ül- 'be seen' (Róna-Tas 1998: 75; Johanson 1998: 42). In Kazakh (and Turkish), the verbal form with -1- is bi-functional. It serves to form both "non-passives without implied agents", e.g. yesik aš-1l-dı 'the door opened' (Kazakh), and "true passives with implied agents" 'the door was opened (by someone)' or, in other words, "intransitivized transitive verbs" (şahan Güney 2006: 128).

When a verbal stem ends in a vowel or $-\mathbf{l}-,-(\mathbf{V}) \mathbf{n}$ - is in Turkic used to indicate passivization, e.g. s1:- 'break (trans.)' $\rightarrow$ s1-n- 'break' (Clauson 1972). ${ }^{7}$ This then coincides with the verbal suffix $-(\mathrm{V}) \mathbf{n}$ - which indicates reflexivity, e.g. yu:- 'wash (trans.)' $\rightarrow$ yu:-n- 'wash oneself' (ibid.: $870 \&$ 942). Therefore, verbal forms in -n- under some conditions can express either passivity or reflexivity, e.g. kör-ün- (< kör- 'see'): 'to be seen' (passive), 'become visible' (reflexive). A third signification of $-(\mathrm{V}) \mathbf{n}$ - is the middle voice, e.g. Karakhanid al-ïn- 'take for oneself' (< al- 'take') (Johanson 1998: 42). The form of the vowel $\mathbf{V}$ in the passive and reflexive suffixes is subjected to the principles of fourfold vowel harmony in nearly all Turkic languages: $u / \ddot{u}$ (rounded: back/front) and $1 / \mathrm{i}$ (unrounded: back/front). These cannot be rendered in Arabic script (on Kipchak passive suffixes, see Berta 1998: 160).

\section{Passive and compliance in the sources}

21 The question is how the sources deal with passivization and compliance as semantic concepts, how they link the voice to morphemes such as $-(\mathrm{V}) \mathbf{l}-$ and $-(\mathrm{V}) \mathrm{n}-$, the distribution of these morphemes, and the concepts these morphemes are associated with -i.e. the internal passive or a derived form- and which terminology is used for the notion of stem for suffixes. ${ }^{8}$

The Turkic passive is dealt with in the sources in different contexts. Unlike Arabic, the past tense verb is not close to the unmarked form, but expressed by an ending, -DI, attached to the stem. The Turkic stem alone expresses the imperative. Some sources, as we shall see, discuss the passive in the context of the passive participle, which in Turkic merely requires the appropriate passive suffix to the stem, plus one other suffix which expresses the participle. In Arabic, the passive participle is expressed by means of a combination of a pre- and infix.

In 'Idrāk, 'Abū Ḥayyān uses three different expressions: the first is related to the voice of the verb (mā lam yusamma fắ iluhu '[the verb] whose agent is not expressed'), the

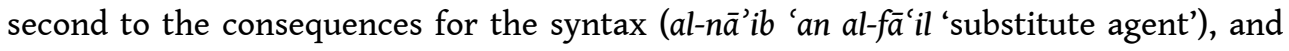
the third to the semantic notion of the resultative (muțāwa' $a$, lit. 'compliance'). 


\subsection{The distribution of $I$ and $n$}

In some sources, the logic behind the distribution of $l$ and $n$ is not explained at all. In the Margin Grammar for example, the author writes quite vaguely that the rule regarding the use of $l$ and $n$ is what one actually hears ( $a l-s a m \bar{a}^{c}:$ MG 36a top). Kāšgarī writes at the entry 'agirla-n- (< 'agirla- 'praise', 'ukrima 'he was praised') that $n$ in this verb can be replaced (mubdala) by $l$, yielding the alternative form 'agirla-l-, but he does not explain why (Dīwān 148,6; Clauson 1972: 94).

The Margin Grammar writes that an unvocalized $l$ is added before the marker of the personal pronoun (mudmar), i.e. probably in case of the past tense verb, or before the marker of the future tense (istiqbāl) (MG, 37B right) - an important note, since in Arabic the imperfect tense, used for the future tense, contains elements that express gender and number.

\section{Kāšğarī states:}

For every biradical (tuna $\bar{a} \hat{\imath})$ transitive (muta'addì) verb, if you add an $l$ to it, it becomes an intransitive (lāziman) and passive verb (mağhūlan) as explained before.

Wa-kull fi'l 'id̄a kāna tunā'iyyan muta'addiyan fa-'id̄a 'adHalta fihi al-lāma yakūnu fi 'lan lāziman wa-fi lan maǧhūlan kamā maḍā. (Dīwān 490)

The anonymous author of Qawānin provides a short analysis:

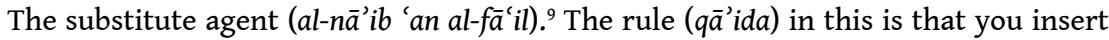
(tuqhim) an unvocalized $l$ [or an unvocalized $n$ ] between the imperative form and whatever marker follows.

Al-nā'ib 'an al-fā'il - al-qā'ida fihi 'an tuqhim lāman sākina ['aw nūnan sākina] bayna fi'l al-'amr wa bayna mā yalì min 'alāma. (Qawānīn 26)

The author does not elaborate further. Yet 'Abū Hayyān in a very concise manner provides more detailed rules regarding the distribution of -n-:

If [the verb] is uniradical or biradical, and its second consonant is either vocalised or a silent $l$, or if [the verb ends in] lā, which serves the action ('amal), the addition (mazid) is an unvocalized $n$ ('Idräk 133).

'Abū Hayyān bases his distribution of -n-, on the following criteria:

1. the verb is uniradical, i.e. CV-or

2. the verb is biradical:

a. the final consonant of the [biradical] verb is vocalized (i.e. the stem ends in a vowel), i.e. CVCV- or

b. it ends in an (unvocalized) $l$, i.e. CVl- or

3. the verb, of any length, ends in lā- (examples below).

Qawānin describes four contexts which determine the form of the suffix, i.e. when an $n$ is used:

The rule (dābit) regarding the position (mawdi $\left.i^{\prime}\right)$ of the $n$ is [1] that the verb ${ }^{10}$ consists of one single consonant, like $y$ [i.e. ya-] meaning 'eat!' (kul), [2] or of two consonants, the second of which is vocalised (mutaharrik), like tuša, meaning 'spread!' (ufruš), [3] or it consists of two consonants the second of which is not vocalised, but it is an $l$ [that is used], e.g. 'al meaning 'take!' (Hud), șal meaning 'throw!' (irmi), [4] or the verb has more consonants, the final one being lā which 
serves the action ('amal) [i.e. used to construct denominal verbs], e.g. yumruq-lā [< yumruq 'fist'] 'punch!' (ulkum) 'aylā! 'work!' [< 'ay e:d 'material'11] (i'mal) and sūy-lah! [< söz 'word'] 'talk!' (tahaddat) and the like. These are the positions of the $n$, and all the rest [is] the position of the $l$. [5] So you say in the constructions of these examples according to their order: yi-n-il-dì ['he was eaten'] and tuša-n-dì ['it was spread'], 'al-in-ḍi ['it was taken'], șal-in- ḍi ['it was thrown'], yumruq-la-ndī [< yumruq 'fist' > yumruq-la- 'to punch'] ['he was punched'] and sū-la-n-dī [< sū 'water' > sū-la- 'to water'] ['it was watered'] and use this as a general rule (qis).

Wa-l-dābiṭ li-mawdị' al-nūn 'an yakuna al-ismu [sic, al-fi'l, R.E.] [1] 'alā harf [wāhid] nahwa ya bi-ma'nā 'kul'. [2] 'aw 'alā harfayni wa-l-țānī minhumā mutaharrik naḥwa tuša bi-ma'nā ufruš'. [3] wa-'ala harfayni wa-l-țānī minhumā sākin wa-lakinnahu lām, nạ̣wa 'al bi-ma 'nā 'Hud', wa-șal bi-ma 'nā 'irmi'. [4] aw yakūna al-fi'l 'alā 'aktar min diālika wa-

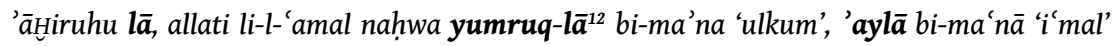
wa-sūylah bi-ma 'nā 'tahaddaț' wa-naḥwa dalika. Fa-hādihi mawādì' al-nūn wa-mā 'adāhā mawḍi al-lām. [5] Fa-taqūlu fì binā' hādihi l-'amtila 'alā t-tartīb yi-n-il-dī wa-tuša-n-dī, 'al-in-d̄ī, șal-in-ḍi, yumruq-la-n-dī wa-sū-la-n-dī wa-qis 'alā dālika. (Qawānīn 26)

If we rephrase Qawānīn's statements in a more formal notation, the following picture of the distribution of $n$ emerges:

1. CV- -one consonant, e.g. ya-;

2. CVCV- -two consonants, a vowel follows the second consonant, e.g. tuša-;

3. CVl- - two consonants, the last one being an l, e.g. șal-;

4. - lāa -verbal stem ends in -lāa - this category includes denominal verbs -e.g. yumruq-lāa-, a denominal verb from yumruq 'fist'.

Yet the examples Qawānin gives still deviate from these rules. For example, instead of yi-n-il-dí, ['it was eaten'], which contains a combination of $n$ and $l$, i.e. a two passive suffixes on the stem yi- 'to eat', one would expect a form like yi-n- $\cdot{ }^{13}$ Another point is that in his account the anonymous author does not account for the distribution of $l$.

If we combine this statement with 'Abū Hayyān's concise summary, it evolves that they are essentially identical:

1. (CV)CV- -one or two consonants;

2. (CV)CVl- -two consonants, the final one being an l;

3. verbal stem ending in $-\mathbf{l a}$.

The limitation in both sources on the number of consonants is difficult to understand as there are many verbs consisting of more than two consonants, not ending in -lā to which -n- can be added.

\section{2 $L$ and $n$ as markers of the internal passive}

All sources deal with the internal passive, yet not in the same way. Qawānin, for example, relates Turkic $l$ and $n$ to the Arabic $u$-i pattern in the unmarked verb: "The rule $\left(q \bar{a}^{\prime} i d a\right)$ in this is that $n$ is that you insert (tuqhim) an unvocalized $l$ [or an unvocalized $n$ ] between the imperative form and whatever marker follows" (cf. also 4.1). Examples (without Arabic equivalents) are ya-n-il-dì 'it was eaten' (which contains a double passive, one -n, directly after the stem, ya- 'eat', and a second passive suffix in -il-), tuša-n-dī 'it was spread out' [< tuša-], 'al-in-ḍi 'it was taken' [< 'al- 'take'], șal-indịi 'it was set free' (< șal-), yumruq-la-n-ḍī 'he was punched' [< yumruq-la- 'to punch' 
[denominal v. $<$ yumruq 'fist'], sūla-n-dī 'it was watered' [ sū-la-, denominal v. $<$ sū'water'] (Qawānin 26). ${ }^{14}$

'Abū Ḥayyān briefly discusses the passive form with -Vl- under the heading "Chapter on the addition" (al-Qawl fi al-ziyāda) where a great number of nominal and verbal are listed ('Idrāk 111-116). He writes: "[the 1] is added (tuzādu) as an indication (dalālatan) that [the verb] is 'formed for the passive form"' (binā' al-fi'l li-l-maf $\left.{ }^{\prime} \bar{u} l\right)$ ('Idrāk 115), i.e. the internal passive:

Not only l, according to 'Abū Hayyān, but also $n$ serves the function of marker of the internal passive as well. Elsewhere, in the "Chapter on the substitute of the agent" ('Idrāk 133), 'Abū Hayyān gives the following examples of $n$ and the internal passive: yadì - 'akala, ya-n-dī - 'ukila; și-dī - kasara, si-n-dì - kusira. Some of these examples recur in a summary under the header "the logical object whose agent is not mentioned" (al-maf'ūl mā lam yusamma al-fā'ilu-hu) ('Idrāk 112) albeit without translations into Arabic.

\begin{tabular}{|l|l|}
\hline (3) & 'ur-il-dì \\
\hline & beat-PASS-3sg.PAST \\
\hline & 'he was beaten' \\
\hline
\end{tabular}

\subsubsection{The passive participle}

The author of the Margin Grammar chooses an approach based upon the passive participle, which in Turkic is marked by a passive stem plus the ending -KAn:

[1] The "passive participle" in Arabic -as is well-known - can only be [derived] from the transitive verb (al-fil al-muta 'addi); the same is true in Turkic. [2] Its marker ('aläma) [i.e. of the passive participle] is that you insert (tudHil) an unvocalized (sākin) $l$ or an unvocalized (sākin) $n$ between the basic imperative verb (fi'l al-'amr al-muğarrad) and the marker of the connected agent (al-fác'il al-mawșül).

[1] Ism al-maf'ūl - wa-qad 'ulima fì al-'arabiyya 'annahu lā yakūnu 'illā min al-fi'l almuta'addī fa-kad̄alika fi al-turkiyya. [2] Wa-'alāmatuhu 'an tudHila bayn fi'l al-'amr almuğarrad wa-'alāma al-fā'il al-mawșūl lāman sākinan (sic) 'aw nūnan sākinan (sic). (MG 36a top)

The author here says, first, that a passive form can only be construed from a transitive verb. This is not entirely true, because in Arabic grammar intransitive verbs, e.g. dahaba 'go', the formation of impersonal passives is allowed (Girod 2007: 315): e.g. duhiba 'ilā al-qudsi, lit. 'it was went to Jerusalem' (Saad 2019 [1982]: 2).

He then explains that the marker $l$ is put after the stem, but before -KAn. He

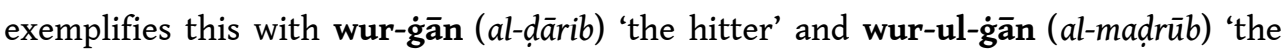
one that is hit'. He then analyses the participle ending - $\dot{\mathrm{g} a} \mathbf{n}$ as the marker of the connected agent (al-fä́ ${ }^{\prime} i l$ al-mawșūl), and thus appears to assign other significations to it, perhaps because this same ending is also used for the active participle. The Turkic ending does not contain any information regarding gender, number or passivity:

41 A similar statement can be found in Tuhfa. The passive participle (ism al-maf $\bar{u}$ ul) and the passive according to the pattern fu' ila (al-mabni li-mā lam yusamma fá 'iluhu): 
"Its marker [i.e. of the passive participle] is an unvocalized $l$ which follows (tali) the $\operatorname{verb}\left(f_{i}{ }^{l} l\right)$ [i.e. the verbal stem] in the three tenses ( $\left.h \bar{a} \bar{l} \bar{a} t\right)$ for all pronouns".

'Alāmatuhu lām sākina talī al- fi' l țalāt ḥālāt fì jamī' aḍ-damā'ir. (Tuhfa 47v5)

The Arabic examples given here, surprisingly, contain conjugated verbs with the internal passive rather than their passive participles, e.g. musiktu ('I was taken') and their Turkic equivalents with -(V)l-, e.g.:

\begin{tabular}{|l|l|}
\hline (4) & wur-ġān \\
\hline & hit-PART.PAST \\
\hline & 'the hitter', 'who was hit' \\
\hline
\end{tabular}

\begin{tabular}{|l|l|}
\hline (5) & wur-ul-ḡān \\
\hline & hit-PASS-PART.PAST \\
\hline & 'the one that is hit' \\
\hline
\end{tabular}

\begin{tabular}{|l|l|}
\hline (6) & țūte $\mathbf{u} \mathbf{l}-\mathbf{d u} \mathbf{u}-\mathbf{m}$ \\
\hline & take-PASS-PAST-1sg \\
\hline & 'I was taken' \\
\hline
\end{tabular}

\subsection{2 $\mathrm{K}$ as a marker of passivity}

In Turkic, there is a considerable number of deverbal adjectives ending in $-(\mathrm{V}) \mathrm{K}^{15}$ (i.e. ik, -uq, etc.). ${ }^{16}$ It makes sense to consider it a marker of passivity, albeit in a limited context, e.g. ač-uk 'open' (< ač- 'open'), yar-uq 'split' (< yar- 'to cleave'), oy-uq 'hole' (< oy- 'to hollow out'), and yül-ük 'shaven' (< yül- 'to shave'). ${ }^{17}$ The formation of these adjectives is, as far as I know, not productive.

These adjectives in -(V)K can be translated with passive participles in Arabic. This is the approach chosen in Tuhfa. Tuhfa (p. 48r) lists thirteen Arabic passive participles (of the maf $\bar{u}$ l pattern) along with their Turkic equivalents, all of them ending in -Vq/-Vk, e.g. maftūḥ - 'ağ-īq 'open', mašqūq - yār-īq 'split', maḩzūz - kārt-īk 'notched' $\left[<\right.$ kert- 'to notch'] ${ }^{18}$ suggesting that $-(\mathrm{V}) \mathrm{K}$ is a marker of passivity. As we shall see, Ibn Muhannā too considers $q$ to have this function (cf. 4.3.1), but he mistakes sin-uq- for a verbal stem.

Kāšgarī takes this same reasoning regarding the use of the variants of -(V)K one step further as he considers them verbal augments in relation to the passive voice of a verb (p. 328). He gives two exemplifying phrases with a verb in $-(\mathrm{V}) \mathrm{K}$ which he translates with an Arabic internal passive. Note that in Turcological studies $-(\mathrm{V}) \mathrm{K}$ is not considered a productive suffix with verbal stems. ${ }^{19}$ 
The Turkic verb [bassiq-], Kāšğarī writes, derives from an original form ('aṣl) bas-dī plus the harf $q$. Bas- is, in fact, a common verb which is used in the sense of 'to attack'. In Kāšgarī’s view, the verb in $7 b$ too consists of a stem (bal-) plus the suffix $k / q$. In Turcology though, baliq is not derived from the stem bal-, but from an obsolete stem ba:. ${ }^{20}$ Kāšgarī seems to acknowledge this, because he lists bālig as a noun elsewhere in his work, with the meaning 'the wounded one' [al-ğarîh, p. 205; also p. 107 \& 131]. Perhaps a more accurate translation of $7 \mathrm{~b}$ therefore may be 'the man was a wounded one'.

\begin{tabular}{|l|l|}
\hline (7a) & bass-iq-tî ' ar \\
\hline & buyyita al-rağulu \\
\hline & 'the man was suddenly attacked' \\
\hline
\end{tabular}

\begin{tabular}{|l|l|}
\hline$(7 b)$ & 'ar baliq-ti \\
\hline & ğuriha al-rağul \\
\hline & 'the man was wounded' \\
\hline
\end{tabular}

\subsection{Turkic $I$ and $n$ as markers of infi'āl and muțāwa'a}

The grammarians could not always decide whether the Turkic augments $l / n$ stood for the internal passive or for other forms. It appears that they prefer the infi' $\bar{a} l$ rather than the internal passive, possibly because this also involves the addition of a consonant.

'Abū Ḥayyān in his 'Idrāk deals with the $l / n$ both in the context of the internal passive, as I discussed above, but also in the compliance. He writes:

If the verb consists of one consonant ('alā harf wähid), like their utterance 'he broke (tr.)' (kasara) si-dī, in the compliance (muțāwa'a) a silent $n$ is used instead of an $l$. Thus for 'he broke (intr.)' (inkasara) you say si-n-dì.

Fa-in kāna al-fi'l 'alā harf wāhid nahwwa qawlihim kasara si-dī fa-l-harf allad̄i gī’a bihi li-lmuțāwa'a nūn sākina badala al-lām fa-taqūlu fi inkasara si-n-dì. ('Idrāk 110)

50 He does not give any other conditions for the change.

51 On the same page, 'Abū Hayyān, again, discusses this $l$ under the heading of "consonant of the compliance" (harf al-muțāwa'a). There he translates the Turkic passive verbal form 3.sg kas-il-dī with Arabic in-qata' $a$, which we can analyse as follows:

It is difficult to tell at this point whether 'Abū Hayyān here refers to the muțāwa' $a$ in the semantical-interpretative sense, or whether he interprets all instances of infi ${ }^{i} \bar{a} l$ as muțāwa' $a$ throughout. The lack of any context in this phrase suggests that the latter may have been the case. 
uthor of the Margin Grammar is more explicit. According to him [in Turkic], no distinction is made between the "passive form" (mā lam yusamma fä́ iluhu) and the infi $\bar{a} \bar{l}$ form: they overlap. In Turkic, he writes:

[1] There is no difference between this form [i.e. the form in fu'ila] and the infi'alform; both are rendered by means of addition (ziyāda) of the l, regardless of whether it is in the past tense (mādī) or the future tense (mustaqbal).

[2] You say for example 'ur-ul-dī i.e. 'he was beaten' (duriba) and likewise aṣ-il-dī 'he was hung' (șuliba), and 'ič-il-dī 'it was drunk' (šuriba) and the like.

[3] The difference between al-infi'âl and [the form fu'ila] is that al-infi'āl is intransitive (lāzim) [while] this [the base form without -1-] is transitive (muta'addin). $[\ldots]$

[4] the infi'âl occurs with an $n$, you say 'ari-n-dî ['he is cleansed'] or the infi'âl-form of 'the cleansing' (al-nazāafa), and likewise kur-u-n-dî ['he is seen'] or the infi'âlform of 'the staring' (al-'ibșār).

[1] Bāb mā lam yusamma fã ilu-hu - lā farqa bayna-hu wa-bayn al-infi'āl fi ziyāda al-lām

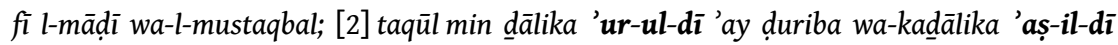
'ay șuliba wa-kad̄ālika 'ič-il-dī' ay šuriba wa-naḥwa-hunna. [3] Wa-l-farq bayna al-infi'āl wa-bayna-hā 'anna al-infi'āl lāzim wa-had̄ā muta'addin [...] [4] wa-qad ya'tī al-infi' āl bi-l-

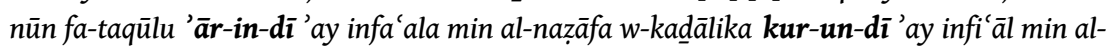
'ibșār. (MG 52A right)

The reference to the tenses is not without importance either. In Arabic, the past tense verb of the 3.m.sg is the standard form without any additional consonants. The present/future tense (mudāri' or mustaqbal) is formed by means of an extra prefix and a change in the pattern of the stem, e.g. in daraba/yadribu ('he hit'/'he hits or will hit'). In the Turkic verbal paradigm, these are only added to the verbal stem.

According to Kāšğarī, the effect of the insertion of $n$ is that "the verb shifts from transitivity to intransitivity" (fa-lamma 'adHalta al-nūna yuqlabu al-fi'l min al-ta' diya 'ilā llāzim: (Dīwān 490). ${ }^{21}$ Kāšğarī suggests that both in Turkic and Arabic there is a similar morphological process in which the $n$ causes intransivity: ${ }^{22}$

'ar tukūn yaz-dī (halla al-rağul al-'uqda) 'the man loosened the knot' but then the $n$ is attached and they say tukūn yaz-in-dīi ${ }^{23}$ i.e. 'the knot is loosened' (inhallat al'uqda) and the verb has become intransitive because of the attachment of the $n$ to it.

'Ar tukūn yaz-dī' 'ay halla al-rağulu al-'uqdata țumma yulhaqu bi-hi al-nūn fa-yuqālu tukūn yaz-in-dī' ay inhallat al-'uqdatu fa-șāra al-fi' l lāziman bi-'ilhāa al-nūn bihi. (Dīwān 490-491) 


\subsubsection{Ibn Muhannā on the internal passive and infi ‘āl}

In his work Hilyat al-Insān, Ibn Muhannā writes a brief yet elaborate explanation of the passive forms. He announces a discussion of three items: "the fourth chapter on [1] the verb whose agent is not mentioned ( $f^{\prime}$ 'l mā lam yusamma fä'iluhu), i.e. the fu' 'ila form [2] the form infi'āl and [3] the form tafa "ul"25 (Hilyat 129). The patterns infi'âl and tafa "ul are in Arab grammar often used in the context of compliance (muțāwa'a).

Then Ibn Muhannā proceeds with a description of four instances in which in Turkic an unvocalized $l$ is added. His point of departure is formed by the contexts in which one of the passive forms is used in Arabic. The first of these is the internal passive (mağhūl) in which the $l$ is, in Ibn Muhannā's terms, inserted ('adHalta) to the "roots" ('ușull) of the verb, e.g.:

- 'aHada - 'al-dī', 'uHida - 'al-il-dī' 'he took', 'he was taken';

- daraba - 'ur-dī, duriba - 'ur-ul-dī, 'he hit', 'he was hit';

- kasara - sin-dur-dī, kusira - sin-dur-.l-dī, 'he broke', 'he was broken'.

In all of these examples, the Arabic equivalents have the internal passive. The Turkic forms differ from another. The choice for 'al-il- is peculiar, for the regular passive form of 'al- is, according to the rules, 'al-in-, 'al-il- being quite rare (Clauson 1972: 145). Further, sin-dur- is surprising too, because it is a causative form (-dur-) and the passivization process shown here (sin-dur-ul-) thus contains a cluster of one causative and one passive suffixes.

Secondly, Ibn Muhannā explains, the unvocalized $l$ in Turkic occurs as a marker where in Arabic the verbal pattern infa'ala is used. He illustrates this with the following examples:

- tahura 'he was clean' - 'arī-dīi, tatahhara ${ }^{26}$ - 'ar-îl-dī 'he was cleansed';

- 'allaqa 'he hung' - 'as-dīi, ta' allaqa - 'as-îl-dī 'he was hung';

- farraqa 'he separated' - tag்-dī, tafarraqa - tag்-ìl-dī 'it was dispersed'.

Interestingly, while all Turkic forms indeed contain a passive in -Vl-, none of the Arabic examples are an actual illustration of the VII pattern (infa'ala). Instead, they are all V forms (tafa"ala). Perhaps Ibn Muhannā did not intend to refer literally to the VII infa' ala form but rather the notion of muțāwa' $a$ often associated with this pattern.

In the third place, according to Ibn Muhannā, a $q$ is used as a marker of passivity, e.g.:

- kasara, s.n-dī 'he broke', takassara, s.n-uq-dī 'it was broken'.

Yet a verbal stem s.n-uq-, as far as I know, does not exist; the form sin-uq is an adjective to which, in a regular procedure, a past tense ending can be added (Clauson 1972: 837). Moreover, while no doubt derived from the verb s1- 'break', the adjective already contains -n-, which denotes passivity. In proposing here $q$ as a suffix, Ibn Muhannā either follows Kāšğarī (cf. 3.2.2), who also proposes $q$ as a marker of passivity, albeit with a less adequately chosen example, or, alternatively, he has had access to sources used by Kāšs̆grī.

4 In a fourth statement, Ibn Muhannā remarks that instead ('iwad) of the $l$ and the $q$ an unvocalized $n$ can be used. The condition for using $n$ is, he writes, that the preceding consonant is vocalized with an a (maftūh) or a $u$ (madmüm). This same $n$ also serves as the marker of the equivalent to the $\mathrm{V}$ tafa " $u l$ pattern, the reflexive:

- $\dot{g} a s a l a-\mathbf{y} \overline{\mathbf{u}}-\mathbf{d} \mathbf{i}$ 'he washed', taǵassala - yū-n-dī 'he washed himself' 
- harraka 'he moved (tr.)' - t.brā-dī 'he moved (intr.)', taḥarraka - t.brā-n-dī 'he (was) moved'.

Ibn Muhannā here appears to be saying that in regard to $n$, in Turkic no difference is made between the internal passive and the other passive forms. However, again, neither of the two examples he gives is an internal passive. In addition, his choice of the second Turkic example, t.brā-dī is not very adequate, since it is intransitive and clearly not the equivalent of the transitive verb harraka. ${ }^{27}$

\subsubsection{Kāšğarī on the combination of $I$ and $n$}

The suffixes $l$ and $n$ occasionally occur in combination with each other in Turkic verbs, e.g. yaz-l-in- 'become loose' and yuv-lu-n- ${ }^{28}$ 'roll'. In the reasoning of the Arab grammatical tradition, doubling poses a problem, since these are both meaningful suffixes which essentially serve the same function. Although Kāšgarī (490-411) does not mention this theoretical problem, he analyses the facts in some detail, in relation to the passive-reflexive verbs yaz-li-n- 'become loose' and yuv-lu-n- 'roll (pass.)' [< yuv- 'to roll (trans.)'], which convey the same meaning as the simpler alternative passive forms yaz-il- and yaz-in- and yuv-ul-, respectively. In Kāšgarī's analysis, many of the issues discussed above come together:

[1] Then the $n$ is combined (turakkabu) with the $l$ and they say yaz-li-n-dī, i.e. 'the knot loosens by itself' (inhallat al-'uqdatu bi-tab'ihi) (sic).

[2] They also say 'ar tubuq yuv-dīi 'the man rolled the ball' (dahrağa al-rağul alkurrata). Then they say tubuq yuv-ul-dí 'the ball was rolled by the action of something else' (duhriğat al-kurra bi-fi'ili gayrihi). The same applies in case of [the Arabic verbal form] tadahrağa 'it rolled (intr.)' [i.e. there is no implied agent]. Then the $n$ is attached to it (yulhaqu), and they say yuv-lu-n-dī, i.e. 'it rolled by itself' (tadahrağa bi-țab'ihi).

[3] Before the attachment of the $n$ to the $l$ [i.e. yaz-il-], the verb was transitive (läziman) in two aspects (wağhayni). One of them ${ }^{30}$ was that the action affected it [i.e. the semantic object] (wāqi 'an 'alayhi) through an unknown agent (fá'il mağhūl) and the verb follows the same course (mağrā) as the $l$ in it..$^{31}$

[1] tumma turakkabu al-nūn ma'a al-lām fa-yuqāl yaz-li-n-dī 'ay inhallat al-'uqdatu bitab 'ihi [2] wa-kad̄ālika yuqālu 'ar tubuq yuv-dī' ay dahrağa al-rağul al-kurrata. Tumma yuqālu tubuq yuv-ul-dī 'ay duhriğat al-kurra bi-fi'li gayrihi wa-kadālika 'id̄ā tadahrağa tumma yulhaqu bihi al-nūn fa-yuqālu [491] yuv-l-un-dī' 'ay tadahrağa bi-țab 'ihi. [3] faqabla 'ilhạq al-nūn bi-l-lām kāna al-fíl lāziman 'alā wağhayni, 'ahaduhumā kāna yağūzu 'an yakūn al-fi' lu wāqi' an 'alayhi min fā'il mağhūl fa-yağrī al-fi'lu mağrā al-lām fihi.

What Kāšgarī appears to be saying in this section is that yuv-ul- is a passive form with an implied, hidden (or unknown) agent. Yet after the addition of the $n$, resulting in yuv-lu-n-, which contains a (vowel shift and a) combination of suffixes -impossible in Arabic-, the verb looses the notion of implied or hidden agent and the action is carried out by itself (bi-tab'ihi), expressed in Arabic by a passive-reflexive form such as tadahrağa..$^{32}$ Thus he not only distinguishes semantically and functionally the Arabic internal passive from the infi'a $\bar{l}$-form, he also assigns distinct functions to Turkic verbal morphemes. 


\subsection{The distinction between stem and root}

68 that are attached to the verbal stem in order to indicate the passive form. Yet there are different points of confusion as to the distribution of these suffixes. For example, for some reason they link the distribution of the $n$ to mono- or biradical verbs.

71 Another problem is the signification. In Arabic, the passive can be expressed by means of an internal passive along the patterns / fu' ila/ - a change within the root (wazn) - or /maf'uwl/, or via changes to the root, VII infa' ala or V tafa "ala each signifying different things. While the internal passive refers to an unknown, hidden agent, the VII and V forms refer to an absent agent, the subject of the verb carries the action out by itself. These forms are used in the concept of compliance, the resultative (muțāwa'a) in which an agent carries out the action, while there is a causing element. In Turkic no such differences exists and $n$ can be assigned the same signification as the equivalent suffix in Arabic: intransitivization. Most sources take the functional overlap of $l$ and $n$, when transferred to Arabic, for granted; only the Margin Grammar explicitly says that they coincide. It seems the authors are confused by this overlap; they would have preferred to assign the Turkic suffixes $l / n$ distinct functions.

\section{Primary sources}

Al-Andalusī, 'Abū Ḥayyān. Kitāb al-'Idrāk fì lisān al-'Atrāk. Ed. by A. Caferoğlu. Istanbul: Evkaf. 1931.

Al-Andalusī, 'Abū Ḥayyān. Kitāb Manhaj al-sālik fĩ al-kalām 'alā Alfìyyat Ibn Mālik. Ed. by S. Glazer. New Haven CT: American Oriental Society. 1947. 
Al-Andalusī, 'A bū Ḥayyān. Irtišāf al-Ḍarab fï Lisān al- 'Arab, vol. I, II, III. Ed. by. M.A. al-Namās. Cairo: Al-Madanī. 1984, 1987, 1989.

Halasi-Kun, T. ed. Al-Tuhfa al-Zakiyya fì al-Luġa al-Turkiyya / La langue des Kiptchaks d'après un manuscrit arabe d'Istanbul, II, Édition phototypique. Budapest: Bibliotheca Orientalis hungarica. 1942.

Houtsma, M. Th. ed. Tarğumān Turkī wa-Ağami wa-Muġālī / Ein türkisch-arabisches Glossar nach der Leidener Handschrift. Leiden: Brill. 1889.

Ibn Al-Muhannā, Ǧ.-D. Kitāb Hilyat al-Insān wa-Halbat al-Lisān. Ed. by M.R. Kilisli. Istanbul: Matbaa-1 Âmire. 1921.

Al-Kāšğgarī, M. Dīwān Luġāt at-Turk. Facsimile edition of Ali Emiri 4189. Ankara: Kültür Bakanlığ1 [Ministry of Culture]. 1990.

Kilisli, M.R. ed. Kitāb al-Qawānīn al-Kulliyya li-Ḍabt al-Luġa al-Turkiyya. Istanbul: Evkaf. 1928.

\section{Secondary sources}

Abboud-Haggar, S. 2006. Dialects: Genesis. Encyclopedia of Arabic language and linguistics 1, 613-622. Leiden: Brill.

Al-Balushi, R. 2016. Omani Arabic: More than a dialect. Macrolinguistics, $\mathrm{n}^{\circ} 4 / 4:$ 80-125.

Auezova, Z.-A. 2005. Mahmud Al-Kashgari: Diwan Lughat at Turk. Kazakhstanskie Vostokovednye Issledovaniia. Almaty: Daik Press.

Ayoub, G. and Versteegh, K., eds. 2018. The foundations of Arabic linguistics, III, The development of a tradition: Continuity and change. Studies in Semitic languages and linguistics 94. Leiden: Brill.

Baalbaki, R. 2009. Așl. Encyclopedia of Arabic language and linguistics 4, 192-195. Leiden/Boston: Brill.

Bazzi-Hamzé, S. 2007a. Fā il. Encyclopedia of Arabic language and linguistics 2, 83-84. Leiden/Boston: Brill.

Bazzi-Hamzé, S. 2007b. Fi'l. Encyclopedia of Arabic language and linguistics 2, 90-96. Leiden/Boston: Brill.

Belova, A. Gr. 2009. South Semitic languages. Encyclopedia of Arabic language and linguistics 4, 300-315. Leiden/Boston: Brill.

Berta, Á. 1998. Middle Kipchak. In The Turkic languages, ed. by L. Johanson and É.Á. Csató, 158-166. London: Routledge.

Bohas, G. and Guillaume, J.-P. 1984. Étude des théories des grammairiens arabes, 1, Morphologie et phonologie. PIFD 112. Damascus: Institut français de Damas.

Carter, M.G., ed. 1981. Arab linguistics: An introductory classical text with translation and notes. Amsterdam studies in the theory and history of linguistic science. Series 3, Studies in the history of linguistics 24. Amsterdam: J. Benjamins.

Clauson, G. 1965. An Eastern Turki-English dictionary. By Gunnar Jarring. Lunds Universitets Årsskrift, N. F. Avd. 1, Bd. 56, Nr. 4. Pp. 338. C. W. K. Gleerup, Lund. 1964. Kr. 50. Journal of the Royal Asiatic Society of Great Britain and Ireland, $\mathrm{n}^{\circ}$ 97/1: 57.

Clauson, G. 1972. An etymological dictionary of pre-thirteenth-century Turkish. Oxford: Clarendon Press. 
Dankoff, R. and Kelly, J., eds. 1982-1985. Mahmūì al-Kāšyarī, Compendium of the Turkic dialects (Diwān Luүāt at-Turk). 3 vols. Sources of Oriental languages and literatures; Turkish sources 7. Cambridge MA: Harvard University.

Ermers, R. 1999. Arabic grammars of Turkic: The Arabic linguistic model applied to foreign languages \& translation of 'A bū Hayyān al-'Andalusī's Kitāb al-'Idrāk li-Lisān al-'Atrāk. Studies in Semitic languages and Linguistics 28. Leiden/Boston/Cologne: Brill.

Ermers, R. 2007. The use of morphological patterns in Arabic grammars of Turkic. In Approaches to Arabic linguistics presented to Kees Versteegh on the occasion of his sixtieth birthday, ed. by E. Ditters \& H. Motzki, 435-453. Studies in Semitic Languages and Linguistics 49. Leiden/Boston: Brill.

Girod, A. 2007. Impersonal Verb. Encyclopedia of Arabic language and linguistics 2, 315-318. Leiden: Brill.

Johanson, L. 1998. The structure of Turkic. In The Turkic languages, ed. by L. Johanson and É.Á. Csató, 30-66. London: Routledge.

Khawla, M.F. 2012. Al-muțāwa a wa-ta' șịṣu-hā fī al-'Arabiyya. Majallat Jāmi at Tikrìt Li-l-'Ulūm alInsāniyya, $\mathrm{n}^{\circ}$ 19/10: 122-135.

Larcher, P. 2003. Le système verbal de l'arabe classique. 1st ed. Didactilangue. Aix-en-Provence: Publications de l'université de Provence.

Larcher, P. 2009. Verbs. Encyclopedia of Arabic language and linguistics 4, 638-645. Leiden/Boston: Brill.

Larcher, P. 2012. Le système verbal de l'arabe classique. 2nd ed. Manuels. Aix-en-Provence: Presses universitaires de Provence.

Maalej, Z. 2008. Middle verbs. Encyclopedia of Arabic language and linguistics 3, 224-227. Leiden/ Boston: Brill.

Maróth, M. 2009. Qiyās. Encyclopedia of Arabic language and linguistics 4, 11-14. Leiden/Boston: Brill. An-Nādirī, M.A. 1995. Naḥw al-lug̉a al-'arabiyya: Kitāb fì qawāi id an-naḥw wa-ș-șarf. Beirut: AlMaktaba al-'Așriyya.

Owens, J. 1988. The foundations of grammar: An introduction to Medieval Arabic grammatical theory. Amsterdam studies in the theory and history of linguistic science. Series 3, Studies in the history of the language sciences 45. Amsterdam/Philadelphia PA: J. Benjamins.

Owens, J. 1990. Early Arabic grammatical theory: Heterogeneity and standardization. Amsterdam studies in the theory and history of linguistic science. Series 3, Studies in the history of the language sciences 53. Amsterdam/Philadelphia PA: J. Benjamins.

Redhouse, J.W. 1890. A Turkish and English lexicon. Shewing in English the significations of the Turkish terms (Re-pr. 1978). Istanbul: Çağrı Yayınları.

Róna-Tas, A. 1998. Proto-Turkic and the Genetic question. In The Turkic languages, ed. by L. Johanson and É.Á. Csató, 67-80. London: Routledge.

Saad, G.N. 2019 [1982]. Transitivity, causation and passivization: A semantic-syntactic study of the verb in Classical Arabic. Library of Arabic Linguistics 4. New York: Routledge.

Şahan Güney, F. 2006. Functions of the so-called passive morpheme -(I)l- in Kazakh. Bilig, $\mathrm{n}^{\circ}$ 36: 125-137.

Sheyhatovitch, B. 2018. The distinctive terminology in Šarh al-Kāfiya by Radī l-Dīn al-'Astarābādīi. Studies in Semitic languages and linguistics 96. Leiden: Brill. 
Simeone-Senelle, M.-Cl. 1997. The Modern South Arabian languages. In The Semitic languages, ed. by R. Hetzron, 378-423. London: Routledge.

Soltan, U. 2009. Transitivity. Encyclopedia of Arabic language and linguistics 4, 535-542. Leiden/ Boston: Brill.

Versteegh, K. 1995. The explanation of linguistic causes: Al-Zağǧăğì's theory of grammar: introduction, translation, commentary. Amsterdam studies in theory and history of linguistic science 75. Amsterdam/Philadelphia PA: John Benjamins.

Versteegh, K. 1997. Landmarks in linguistic thought III: The Arabic linguistic tradition. Routledge History of Linguistic Thought Series. London/New York: Routledge.

Versteegh, K. 2014. The Arabic Language. 2nd ed. Edinburgh: Edinburgh University Press.

Yavrumyan, M. 2006. Das System der Verbalstämme in der Arabischen linguistischen Tradition. Elemente der morphologischen und semantischen Analyse. Bayreuth: Universität Bayreuth.

\section{NOTES}

1. The author wishes to thank the anonymous reviewer for his critical remarks.

2. The importance of Diwwān is so great, that most Turkic peoples, from Turkey to Kazakhstan, claim it as part of their cultural heritage. In addition, Dīwān formed the basis for Clauson's etymological dictionary of Turkic languages (Clauson 1972).

3. See, e.g. Yavrumyan (2006).

4. /"/ represents the 'alif, which is preceded by /a/ (fatha), which then can only be realised as a long vowel (see Bohas and Guillaume 1984: 256-259).

5. It remains to be investigated whether they discerned new functions that were unknown to the Arabic system.

6. Khawla (2012: 129-130) lists eleven verbal patterns for the muțāwi', one of them, in fu'ila, as in ğada'ahu fa-ğudi' a 'he deceived him, so he was deceived'.

7. Clauson (1972) notes the rare form al-1l- as a passive of al-; also bil-il- 'be known' (< bil-) (Berta 1998: 160).

8. In the sources, the vowels in Turkic morphemes are occasionally not explicitly written; in those cases, a period is used in the transcription, e.g. -.1- and -.n-.

9. On al-nā'ib 'an al-fā'il, cf. Bazzi-Hamzé (2007a: 82).

10. Correction for 'noun': R.E.

11. Clauson (1972: 57).

12. Em. by the editor.

13. The variant ye-n- does exist in the same meaning. The Turkic verb yay- (pronounced with front vowels as [yey-] 'to beat, conquer', yey- [Clauson 1972]) has a regular passive form, i.e. yayil- 'be conquered'. In Ottoman Turkish, the two verbs yen- and yey- have merged into yenmek 'to overcome', 'to be eaten' (Redhouse 1978 [1890]).

14. Qawānin repeats this same text almost literally when describing how the passive participle is formed (p. 51; see discussion in 3.2.1).

15. $\mathrm{K}$ represents the morphemes $k$ or $q$ depending on whether the word is pronounced back or front.

16. Note that in Clauson's transcription of Turkic $-\mathrm{q}$ is not used. Whether a word is pronounced back or front is to be inferred from the vowels.

17. Cf. Clauson (1972: 22, 962, $270 \&$ 928).

18. Cf. Clauson (1972: 22, $962 \& 738)$. 
19. According to Clauson (1972: 337), Kāšğarī here mistakes the -q for the suffix -siq.

20. cf. ibid.

21. If we take this remark to also be valid for verbs with -il-, this is not entirely true, because there are verbs without -1- that are transitive, e.g. igle-1-, (<igle: 'be sick'); a disease igle-l-di 'was suffered' (Clauson 1972: 107).

22. Kāšğarī elsewhere remarks that the $n$ in general causes intransitivity, e.g. for the mediopassive or reflexive verbs (596-597).

23. Correction for yaz-li-n-dī, which Kāšgarī mentions as an alternative later on in the text.

24. A step further would be the suggestion that Kāšgarī believed that - $n$ has a cross-linguistic signification and that it is the same morpheme in the two languages.

25. Numbers added: R.E.

26. Note that tatahhara is the passive form to țahhara 'cleanse', not țahura, as Ibn Muhannā seems to be asserting here.

27. Hence its causative form tepre-t-, cf. Clauson (1972).

28. Cf. ibid.: 987.

29. On yuv- cf. ibid.: 873.

30. Contrary to what one would expect here, a second aspect is not mentioned.

31. On mağrā, see Maróth (2009: 13).

32. Kāšğarī adds in a subsequent passage on the same page that tetra-radical (rubā'î) verbs that are the result of a procedure of combining, such as yuv-lu-n-dī, are transferred (manqūla) from a bi-radical (tuna $\bar{a} \hat{i})$ verb (yuv-) to tri-radical (tulātầ), and from tri-radical to tetra-radical.

33. On 'așl, cf. Baalbaki (2009: 191); Bohas and Guillaume (1984).

\section{ABSTRACTS}

This paper deals with the analyses of medieval Arab grammarians of passive and resultative verbs in Turkic. In Arabic grammatical theory, certain forms are correlated with unique meanings. In Arabic there are basically two types of passives: first, an internal apophonic passive, indicated by a vowel shift within the verbal root, e.g. /fa'ila/ $\rightarrow$ /fu'ila/; secondly, a passive indicated by the prefix in- attached to the root, i.e. Form VII, which results in the infinitive pattern infi $\bar{a}$ l -yet verbal forms construed according to the VII paradigm are in addition often interpreted as resultative verbs. In Turkic, verbs can be passivized by adding an -Vl- to the verbal stem (under some criteria this is -Vn-), e.g. 'ur- 'hit' $\rightarrow$ 'ur-ul- 'be hit'; the Turkish -Vn- form also expresses the reflexive form, e.g. 'ur-un- 'hit oneself'. In addition, other suffixes may indicate passivization. This poses problems for the grammarians, which they tackle in similar but also very distinct ways: the distinctions between the two passive forms in Arabic, the missing resultative in Turkic, the passive in Turkic, the notion of stem in Turkic versus root in Arabic theory, the position of the inserted element, the criteria according to which the Turkic passive form is not -Vl- but instead -Vn-, to name but a few.

Cette contribution se penche sur les analyses des verbes passifs et résultatifs en turcique menées par les grammairiens arabes. Dans la théorie grammaticale arabe, certaines formes sont corrélées à une valeur unique. En arabe, il y a essentiellement deux types de passif : un passif apophonique interne, indiqué par une variation des voyelles à l'intérieur de la racine verbale, e. g. /fa ila/ $\rightarrow$ / fu'ila/, et un passif marqué par le préfixe in- attaché à la racine, autrement la forme VII, qui 
donne l'infinitif infi'âl; toutefois les formes verbales de la forme VII sont en outre souvent interprétées comme des verbes résultatifs. En turcique, les verbes peuvent être construits au passif en ajoutant au radical un suffixe -Vl- (dans certains cas -Vn-), e. g. 'ur- 'frapper' $\rightarrow$ 'ur-ul'être frappé'. La forme -Vn- en turc peut également exprimer la forme réfléchie, e. g. 'ur-un- 'se frapper soi-même'. Il existe en outre d'autres suffixes qui peuvent marquer le passif. Cela pose des problèmes aux grammairiens, qui les traitent de manières diverses encore que voisines : la distinction entre les deux passifs en arabe, l'absence de résultatif en turcique, le passif en turcique, la notion de radical en turcique opposée à celle de racine en arabe, les critères qui distinguent les passifs en -Vl- des passifs en -Vn-, pour n'en nommer que quelques-uns.

\section{INDEX}

Keywords: 'Abū Ḥayyān al-Andalusī, Al-Tuhfa al-Zakiyya fī l-Lug̉a al-Turkiyya, Arabic grammatical theory, Ibn al-Muhannā, Kitāb al-Qawānīn li-Ḍabṭ al-Lug̉a al-Turkiyya, Maḥmūd alKāšgarī, passive in Arabic, passive in Turkic, Turkic grammars in Arabic

Mots-clés: 'Abū Ḥayyān al-Andalusī, Al-Tuhfa al-Zakiyya fī l-Lug̉a al-Turkiyya, grammaires du turcique en arabe, Ibn al-Muhannā, Kitāb al-Qawānīn li-Ḍabṭ al-Lug̉a al-Turkiyya, Maḥmūd alKāšğarī, passif en arabe, passif en turcique, théorie grammaticale arabe

\section{AUTHOR \\ ROBERT ERMERS}

Radboud Universiteit, Nijmegen, The Netherlands 